\title{
MODIFICATIONS TO CORPORATE CONSTITUTIONS IN ALBERTA: AN EMPIRICAL STUDY
}

\author{
RODERICK J. WOOD' \\ MURRAY T. BROWN" \\ RICHARD W. BAUMAN ${ }^{* *}$
}

This study excmines the cotc'mt to which publicly traded Alberta corporations have included provisions. in their corporute romstitutions that modiffi or vary a corporate governance rule that would othensise apply. Part I discussese the notiom of combractual freedom in corporate law and identifies the instance's in which modifications are permilted under the Alberta business corporations statute. Part II outlines the methodology used in carriving out the survey of corporate constitutions and provides a summary of the resulis. Part III provides a more extensive' discussion of the legal framenork pertuining to the rule and ancalyes some of the implications arising out of the results of the sun's?.
La présente étude examine à quel point les sociétés albertaines colées en bourse om previu. dams leurs staturs. des dispessisions modifiant une règle de régie de la socitivi qui de'rait normalement s'appliques: La premicere partic coxamine la notion de liberté contractuelle propre au droit des sociétés et détermine les circomstances où certaines modifications sont permises par la loi albertaine. Lu deuxième partic décrit la méshode utilisée pour effectuer l'enquête sur less statuts de sociêté et fournit le sommaire des résultats. La trovisième partie offre une discussiom plus étenduc du cadre légal relative à la règle et analysse certaines des implications qui découlenl des résultats de l'enquête.

\section{TABLE OF CONTENTS}

1. CONTRACTUAL FREEDOM IN

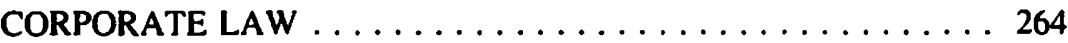

A. MANDATORY AND ENABLING RULES $\ldots \ldots \ldots \ldots .264$

B. DEFAULT RULES IN THE ALBERTA

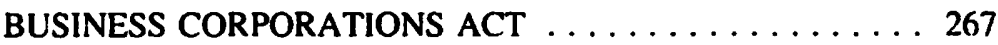

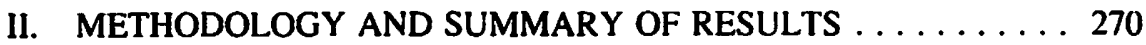

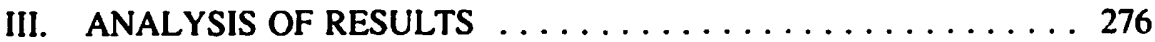

A. RESTRICTIONS ON ACTIVITIES

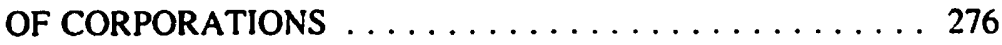

B. MODIFICATIONS RELATING

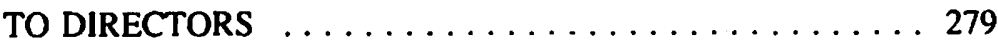

C. MODIFICATIONS TO

SHAREHOLDER VOTING $\ldots \ldots \ldots \ldots \ldots \ldots \ldots 285$

D. MODIFICATIONS TO

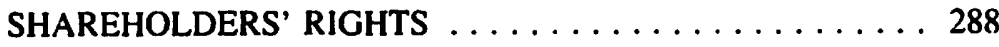

IV. CONCLUSION ....................... 291

R. Wood. Associate Professor of Law, University of Alberta.

- M. Brown. Associate, Howard Mackie, Calgary.

... R. Bauman. Associate Professor of Law. University of Alberta.

The idea for empirical research relating to modifications to corporatc constitutions was developed through conversations between Professors Wood and Bauman. The research was funded in part through a grant from the University of Alberta Small Faculties Endowment Fund. Murray Brown carried out the review of the microfiche corporate records during the summer of 1990 . Professor Wood was responsible for the project design and discussion. We wish to thank Professor Bruce Welling for his comments on a previous draft. 


\section{CONTRACTUAL FREEDOM IN CORPORATE LAW}

\section{A. MANDATORY AND ENABLING RULES}

There is a significant debate under way in the United States concerning the proper role and function of corporation law.' The central question in this debate is a normative one: should corporation statutes be mandatory or enabling in nature. An enabling regime allows management and investors to establish their own system of governance without interference from a regulator. A mandatory regime sets out rules that cannot be waived or varied by the participants. Proponents of an enabling corporate law regime tend to have more faith in the ability of markets to inhibit the misuse of managerial power. ${ }^{2}$ Proponents of mandatory rules are more skeptical of the disciplinary power of markets, and are more inclined to rely upon legal regulation to prevent managers of corporations from acting against the interests of shareholders. ${ }^{3}$ A curious feature of this debate is that there is little agreement on whether, as a matter of pure description, corporation law in the United States is mandatory or enabling."

In one sense, the evolution of corporation statutes in the United States can be seen as a movement towards a more enabling regime. Mandatory features that impeded corporate activity were progressively eliminated. Interstate competition for corporate charters provided the primary mechanism for this phenomena. ${ }^{5}$ On this view, a formal parsing of a corporation statute into mandatory and enabling.provisions is not determinative of the issue. Many of the mandatory features may be unimportant because the rule would be universally adopted, ${ }^{6}$ or can be circumvented through other devices." A market for incorporations renders mandatory rules illusory because of the ease of incorporating in a jurisdiction with a more permissive rule. ${ }^{8}$

This conception of enabling corporation law is different from the notion of an enabling regime as a set of default rules which gives the parties contractual freedom to vary the

- A geod cross-section of upinion can be tound in a symposium on "Contractual Freedom in Corporate Law" (1989) 89 Colum. L. Rev. 1395.

$2 \quad$ Sec. for example, F.H. Easterbrook and D.R. Fischel, "The Corporate Contract" (1989) 89 Colum. L. Rev. 1416.

- Sec V. Brudncy. "Corporate Governance, Agency Costs, and the Rhetoric of Contract" (1985) 85 Colum. L. Rev. 1403; M.A. Eisenberg. "The Structure of Corporation Law" (1989) 89 Colum. L. Rev. $|46|$.

- See J.G. Maclntosh. "Should Canadian Corporate Law be Mandatory or Enabling" (paper presented at 22nd Annual Workshop on Commercial and Consumer Law) lunpublished|.

s See R. Romano. "Law as a Product: Some Pieces in the Incorporation Puzzle" (1985) I J. of Law, Economics and Organization 225; R. Romano, "The State Competition Debate in Corporate law" (1987) 8 Cardozo L.. Rev. 709.

6 B. Black. "Is Corporate Law Trivial?: A Political and Economic Analysis" (1990) 84 Nw. U. L. Rev. 542.

$7 \quad$ R. Romano, "Answering the Wrong Question: The Tenuous Case for Mandatory Corporate Laws" (1989) 89 Colum. L. Rev. 1599. For example, the rule that the shareholders of a corporation must approve a merger can be circumvented by incorporating a wholly owned subsidiary which merges with the target corporation.

x lbid. 
governance rules pertaining to the business organization. The unit of analysis is not the corporation statute (as an aggregation of revealed preferences for governance rules), but the individual firm which for unique reasons may wish to choose a governance rule that would not be chosen by other firms. The corporation statute is viewed as a standard form contract for corporate governance rules which reduces the number of items to be negotiated and the cost of negotiating them. ${ }^{9}$ The parties are free to "opt out" of these rules if they wish to choose a different governance rule." Partnership law provides the best example of this type of enabling regime. The Partnership Act sets out presumptive rules which are subject to variation in the partnership agreement." The presumptive rules operate as "gap-fillers" or "default" rules which apply only in the absence of an express or implied agreement.

The objective of this study is limited. It will not attempt to address the question whether or not Canadian corporation law is enabling in the sense of reflecting the governance rules that most firms would voluntarily choose. On this issue, there is good reason to suspect that the processes that shape Canadian corporation law are fundamentally different from the those at work in the United States. ${ }^{12}$ There is little evidence that inter-jurisdictional competition for incorporations has been a factor in the development of Canadian corporation law. ${ }^{13}$ In Alberta, the shift from the Companies Act model to the Business Corporations Act model of corporation legislation signalled a departure from an explicitly contractarian corporations statute which was a direct descendent of the incorporated partnership and joint stock company. ${ }^{14}$ Under the older statute, the corporate constitution was regarded as a multilateral contract which bound the participants to the govemance rules set out in the constitution..$^{15}$ The incorporators possessed a wide latitude to devise their own governance rules. ${ }^{16}$ By comparison, the

F.H. Easterbronk and D.R. Fischel. "Voting in Corporate Law" (1983) 26 J. of L. \& Econ. 395 at 401.

See B.R. Cheffins, "An Eionomic Analysis of the Oppression Remedy: Working Towards a More Coherent Picture of Corporatc Law" (1990) 40 U. ol Toronto L.J. 775 at 783-88. R.S.A. 1980, c. P-2, s. 21 (presumptive rules governing the mutual rights and duties of partners in relation (o) one another may te varied by the consent of the partners).

1: $\quad$ See R. Daniels, "Should Provinces Compete? The Casc for a Competitive Corporate Law Market" (1991) 36 McGill L.J. 130.

13. Professor Daniels suggests that the rapid adoption of the Business Corporations Act model provides strong evidence of interjurisdictional competitions. However. this is equally consistent with other explanations (such as a desire on the part of legislators to acheive uniformity in corporate-commercial law). Empirical research undertaken by Professor Macintosh does not find any evidence of jurisdiction shopping by corporations. See J. Macintosh. "The Role of Interjurisdictional Competition in Shaping Canadian Corporate Law: A Second Look" (Canadian Association of Law Teachers, Corporate Law Subsection 1992-3) |unpublished). See J.S. Zicgel. "The New Look in Canadian Curporation Laws" in Studies in Canadian Company Law. Vol. 2 (Toronto: Butterworths, 1973) at 68.

is Compenies Act, R.S.A. 1980. c. C-20. s. 21.

in The Compemies Act provided a set of presumptive rules in Table $A$ which applied unless a different rules contained in articles of association were filed. This contractual freedom was used to contract around a variety undesirable corporate law rules (reversal of the fiduciary rule preventing direcions from entering self-dealing contracts: Transvaal Lands Co. v. New Belgitum (Transvaal) Land And Develupment Co.. $|1914| 2$ Ch. 488 (C.A.); avoidance of the rule that the shareholders in a general meeting can overrule the decisions of the directors: Automatic Self-Clensing Filter Syndicute Co. v. 
Business Corporutions Act ${ }^{17}$ provides less opportunity for variation. Furthermore, the movement in Canadian corporations law has been away from a regime of majoritarian rule towards a regime of mandatory minority shareholder protection. ${ }^{18}$

This study adopts the more restricted notion of enabling rules as "default" rules which apply unless displaced by the inclusion of an alternative rule in the corporate constitution. It will identify those provisions of the ABCA which permit variation in the articles of incorporation and it will record the extent to which this ability has actually been used. In addition to mandatory and default rules, it is useful to identify constitutive provisions as a third category. Constitutive provisions are those which require as a condition of incorporation that a choice be made on certain matters and that this choice be specified in the corporate constitution (c.g.. the requirement that the articles of incorporation indicate the corporate name, the number of directors, the classes of shares and the rights allocated to each class).

This study does not cover closely held corporations. Modern Canadian business corporations legislation is unquestionably enabling in relation to these corporations. This is a consequence of the wide latitude given to shareholders to construct alternative governance structures through the use of a unanimous shareholder agreement. ${ }^{19}$ However, the use of a unanimous shareholder agreement is not feasible in the case of a publicly traded corporation where there are many shareholders and frequent transfers of shares. Canadian business corporations legislation in relation to public corporations is largely mandatory in nature. Although there is some scope for variation (such as cumulative voting for directors or increasing the number of votes needed to constitute a special resolution), the salient features of corporate governance are mandatory. Furthermore, an analysis of these provisions indicates that in most cases choice is highly circumscribed. The default rules are not open-ended provisions which invite innovative governance rules. Rather, they typically involve a narrow choice between two alternative rules within the same basic framework of governance rules.

Within this mandatory governance structure there no doubt exists a wide degree of choice over how the management of the corporation is to be organized (unitary centralized management structure or decentralized multi-divisional structure) and how it is to be financed (debt or equity). The allocation of voting and other rights to various classes of shares within this mandatory framework will be of critical importance in defining the allocation of power. However in drafting the primary constitutional documents, the incorporators are given only a limited number of instances in which the adoption of a different governance rule is permitted.

Cuninghame. $|1966| 2 \mathrm{Ch} .34$ (C.A.); circumvention of the ultra vires doctrine by expansive drafting of the ubjects clause: Bell Honses Lid. v. City Wall Properties Lid., |1966] 2 Q.B. 656 (C.A.)).

17 S.A. 1981. c. B-15. as am |hereinafter ABCAl.

Ix These features include greater accessibility of derivative litigation (s. 232 ABCA), the oppression remedy (s. 234 ABCA). the dissent and appraisal right (s. 184 ABCA) and special resolution requirements for several kinds of fundamental changes (e.g., ss. 167. 177. 183 ABCA). liabilities of the shareholders to ont another, provide an alternative method regulating the clection of direciors. restrict or wholly abrogate the powers of directors. 


\section{B. DEFAULT RULES IN THE ALBERTA BUSINESS CORPORATIONS ACT}

The ABCA adopts two kinds of default rules. The tirst variety provide that the modification to the default rule may be contained in the articles of incorporation or a unanimous shareholder agreement. The second variety provide that the modification may be contained in the bylaws, articles of incorporation or a unanimous shareholder agreement. The default rules which allow for modifications in the articles or bylaws are summarized below:

Section 25(1) Articles, bylaws or unanimous shareholder agreement may restrict the right of directors to issue shares.

Section 98(1) Articles, bylaws or unanimous shareholder agreement may restrict the power of directors to make, amend or repeal any bylaws.

Section 98.1(1) Article, bylaws or unanimous shareholder agreement may restrict power of directors to borrow money, issuc debt obligations, give guarantees or grant security.

Section 98.1(2) Articles, bylaws or unanimous sharcholder agreement may restrict ability of directors to delegate their powers to a committce of directors or to officers.

Section 109(2) Articles or bylaws may provide a different quorum requirement respecting meeting of directors (i.e., other than the majority of directors quorum requirement).

Section $112(1) \quad$ Articles, bylaws or unanimous shareholder agreement may restrict the use of a resolution in writing in place of a meeting of directors.

Section $116 \quad$ Articles, bylaws or unanimous shareholder agreement may restrict the power of directors to designate the offices of the corporation. appoint officers, specify their duties and delegate to them powers to manage the business.

Section 120 Articles, bylaws or unanimous shareholder agreements may restrict the power of directors to fix the remuneration of directors, officers and employees of the corporation.

Section 149(1) Articles, bylaws or unanimous shareholder agreement may provide that additional information respecting the financial position of the corporation be included in the financial statements placed beforc shareholders at every annual meeting.

In all but one of these sections, the alternative governance structure envisaged is one in which discretionary power that would normally be exercised by directors is constrained 
by a structural device..$^{\text {D) }} \mathrm{A}$ survey of the publicly registered documents will not produce complete data concerning the incidence of use of these provisions because the provision may be set out in the bylaws of the corporation (which do not need to be registered). For this reason, the primary focus of the survey is on those modifications which must be set out in the articles of incorporation or a unanimous shareholder agreement. Because the shares are publicly traded, it is highly unlikely that the modifications might exist in a unanimous shareholder agreement. As a consequence, a survey of the articles of incorporation will provide accurate data about the frequency of their use.

The default rules which allow for modifications in the articles of incorporation are summarized below:

Section $6(1)(c) \quad$ Articles may restrict the transfer of shares

Section 6(1)(e) Articles may include a restriction on the business that the corporation may carry on.

Section 6(2) Articles may set out any provision permitted to be set out in the bylaws.

Section 6(3) Articles or unanimous shareholder agreement may requirc a greater number of votes for directors or shareholders than that required by the Act to effect any action.

Section $28 \quad$ Articles or unanimous shareholder agreement may provide existing shareholders with a pre-emptive right to acquire new shares in proportion to their holdings.

Sections 32(1), $33(1)$

Section 45(14) Articles may provide that fractional shares are entitled to exercise voting rights or to receive a dividend.

Section 100(2) Articles may require that a director hold shares issued by the corporation.

Section 101(4) Articles may provide for the appointment between annual general meetings of additional directors.

30 The exception is $s$. 109(2) which allows the articles or hylaws to provide a dificrent quorum requirement for mectings of directors. 
Section 101(9)(a) Articles or unanimous shareholder agreement may provide for the election or appointment of directors for terms expiring not later than the third annual meeting following their election.

Section 101(9)(b) Articles or unanimous shareholder agreement may provide for the election or appointment of directors by creditors or employees of the corporation.

Section 102 Articles may provide for cumulative voting.

Section 106(4) Articles or unanimous shareholder agreement may provide that a vacancy among the directors shall only be filled by a vote of shareholders.

Section $109(1)$ Articles may restrict the location for meetings of directors.

Section 126(4) Articles may provide that meetings of shareholders may be held outside Alberta.

Section 160(3) Articles may provide that a vacancy in the office of auditor shall only be filled by vote of the shareholders.

Most of these provisions can be found in the Canada Business Corporations Act ${ }^{21}$ and the other provincial business corporations statutes. ${ }^{22}$ There are three major exceptions in the Alberta Act. The interim director provision which permits the appointment of additional directors otherwise than to fill a vacancy is not found in most other statutes, though Ontario has a somewhat similar provision. ${ }^{23}$ The employee or creditor appointed director was originally unique to Alberta, but subsequently has been adopted in Saskatchewan..$^{2-}$ Finally, the legislators in Alberta chose not to adopt the amendment to the CBCA which provided that the articles could eliminate the need for a separate class votes on certain kinds of amendments to the articles of incorporation."s

For the purposes of analysis these enabling provisions have been divided into the following four categories: (1) restrictions on activities of the corporation; (2) modifications

R.S.C. 1985, c. C-44 |hereinafter CBCA|.

The Nein' Brunswick Business Corporations Act contains major departures from the model in its treatment of pre-emptive rights and cumulative voting. See S.N.B. 198I. c. B-9.1, ss. 27 and 65.

2" The Ontario Business Corporations Act, R.S.O. 1990, c. B.16, ss. 124(2), 125(3) provide a more complex formulation under which a corporation which provides for a minimum and muximum number of directors may appoint additional directors if a special resolution has been passed which allows the directors io establish the number of directors.

S.S. 1984-85-86, c. 44, s. 4. The amendment did not modify the fiduciary obligations of such directors as was done in s. $117(4)$ of the ABCA.

Section $176(1)$ of the CBCA provides that the class vote requirement can be eliminated in the case of an increase or decrease the authorized capital of the class or of another class having equal or superior rights, effecting an exchange, canceltation of all or part of that class or creating a new class having equal or superior rights. 
relating to directors: (3) modifications to shareholder voting; and (4) modifications to shareholder's rights. The survey does not record or evaluate choices made under constitutive rules (rules which require that a choice be made on matters such as the number of directors, the classes of shares and rights pertaining to each class). In one sense, the rule permitting the articles to sct out a limit on authorized capital ${ }^{2 h}$ and the rule that unless the articles provide otherwise each share of a corporation is entitled to vote $^{27}$ might be regarded as default rules which can be varied. However, because these matters are so closely connected with sharc rights detinition, they were classified as constitutive rules.

\section{METHODOLOGY AND SUMMARY OF RESULTS}

The master lists for the Alberta Stock Exchange (ASE) and the Toronto Stock Exchange (TSE) containing the names of all corporations listed on the exchange were obtained. These lists were cross-referenced against the list of corporations obtained from the Alberta Corporate Registry, which contains the name of every corporation incorporated, continued or amalgamated under the $A B C A$. This produced a list of 553 corporations which were incorporated under the $A B C A$ and which were listed on one or both of the ASE and TSE as of April 28, 1990.

The articles of incorporation for each of the $\mathbf{5 5 3}$ corporations were analyzed and the incidence of use of each type of modification recorded. The results of the survey are presented in Table A. Ninety-nine of the 553 corporations were listed on the TSE. Table $A$ also sets out the incidence of use of constitutional modification in respect of these corporations. The corporations listed on the TSE (including those listed on both exchanges) tend to be larger and more established than those listed only on the ASE. A comparison of those corporations listed only on the ASE and those listed on the TSE may therefore provide some evidence as to the incidence of constitutional modifications as a function of enterprise size.

The corporations listed on the TSE were then classified in accordance with the level of share ownership control. The classification was based upon pure shareholder voting power and did not attempt to take into account interlocking directorships which have been taken into account in other studies and reports. ${ }^{28}$ The following three categories were constructed:

(1) controlled corporations: corporations in which a person controls $50 \%$ or more of the shareholder voting power.

(2) dominant shareholder corporations: corporations in which a person controls more than $20 \%$ but less than $50 \%$ of the shareholder voting power.

\section{ABCA. s. 6(1)(a).}

ABCA. s. 134(1).

Royal Commission on Corporate Concentration. Einerprise Siructure and Corporate Concentrution, (Study No. 17) (Ottawa: Queen`s Printer, August 1976): Intercorporate Ownership (Otawa: Statistics Canada, 1990) at xvii-xviii. 
(3) widely held corporations: corporations in which no person controls more than $20 \%$ of the shareholder voting power.

The sources used to create this list were primarily the Statistics Canada Intercorporate Ownership publication for $1990,{ }^{29}$ which is a compilation of ownership (voting equity) information based upon returns under the Corporations and Labour Unions Return Act (CALURA), supplemented by the 1990 Financial Post Survey of Mines and Energy Resources and the 1990 Financial Post Survey of Industrials. This survey was restricted to corporations listed on the TSE since insufficient data was available for those corporations listed only on the ASE. ${ }^{30}$ Blocks of shares held by a security depository (such as Canadian Depository for Securities Ltd.) were not included for the purposes of determining the level of control. ${ }^{31}$ The incidence of constitutional modification as a function of ownership control is presented in Table B.

Corporations are not required to provide in their CALURA returns the names of individuals owning shares or the names of corporations holding less than $10 \%$ of any share class. This factor and the fact that the survey does not attempt to take into account other possible forms of control will mean that the survey may underestimate the level of control that actually exists. It would be a mistake to assume that the corporations classified as "widely held" closely resemble the large widely held corporations in the United States described by Berle and Means." The Financial Post Surveys, which contain information concerning major shareholders including non-corporate shareholders, indicate that in many of these corporations top-ranking managers and directors hold significant blocks of shares.

Ibid.

k) Corporutions und Labour Unions Return Act. R.S.C. 1985. c. C-43. The coverage of the CALURA reports are restricted to those corporations that carry on business in Canada or that are incorporated under a law of Canada or a Province, whose gross revenue for a reporting period exceeded \$15 million. or whose assets exceeded $\$ 10$ million. depossitary holds a large portion of the block for a single person. 1932) at 8-9. These corporations are characterized by widely dispersed shareholding such that no shareholder owns a significant portion of the shares in which the managers own a small fraction of the stock. This produces a situation in which the interests of the owners (shareholders) and the managers diverge. 
Table A

Contitutional Modifications

ASE and TSE Corporations

\begin{tabular}{|c|c|c|c|c|c|c|c|}
\hline & & $\begin{array}{l}\text { ASE } \\
\text { ONL } \\
\end{array}$ & & TSE & & $\begin{array}{r}\text { TorA } \\
\text { (ASE \& } \\
\end{array}$ & \\
\hline $\begin{array}{l}\text { DEscritrion } \\
\text { OP Provision }\end{array}$ & $\begin{array}{l}\text { SECHON } \\
\text { (ABCA) }\end{array}$ & $\begin{array}{l}\text { NUMBER } \\
\text { (454) }\end{array}$ & क & $\begin{array}{l}\text { NumBRR } \\
\text { (99) }\end{array}$ & $\%$ & $\begin{array}{l}\text { NUMBBER } \\
\text { (553) }\end{array}$ & $\infty$ \\
\hline $\begin{array}{l}\text { RESTRICTIONS ON } \\
\text { ACTIVITES OP } \\
\text { CORPORATION }\end{array}$ & & & & & & & \\
\hline Business Restriction & $6(1)(e)$ & 1 & 0.2 & 2 & 2 & 3 & 1 \\
\hline $\begin{array}{l}\text { Restriction Against } \\
\text { Self-Purchase of } \\
\text { Shares }\end{array}$ & $\begin{array}{l}32(1), \\
33(1)\end{array}$ & 0 & 0 & 0 & 0 & 0 & 0 \\
\hline $\begin{array}{l}\text { MODIFCATIONS } \\
\text { RraAting to } \\
\text { DERECTORS }\end{array}$ & & & & & & & \\
\hline $\begin{array}{l}\text { Shareholder Vote } \\
\text { Needed to Fill } \\
\text { Vacancy }\end{array}$ & $1106(4)$ & 0 & 0 & 0 & 0 & 0 & 0 \\
\hline Interim Directors & $101(4)$ & 257 & 57 & 65 & 65 & 322 & 58 \\
\hline $\begin{array}{l}\text { Extended Direcior } \\
\text { Terms }\end{array}$ & $101(9)(a)$ & 58 & 13 & 3 & 3 & 61 & 11 \\
\hline $\begin{array}{l}\text { Employee and } \\
\text { Creditor Directors }\end{array}$ & $101(9)(b)$ & 0 & 0 & 0 & 0 & 0 & 0 \\
\hline $\begin{array}{l}\text { Director Share } \\
\text { Qualifications }\end{array}$ & $100(2)$ & 0 & 0 & 0 & 0) & 0 & 0 \\
\hline $\begin{array}{l}\text { Restriction on } \\
\text { Location of Directors } \\
\text { Meetings }\end{array}$ & $109(1)$ & 0 & 0 & 0 & 0 & 0 & 0 \\
\hline
\end{tabular}




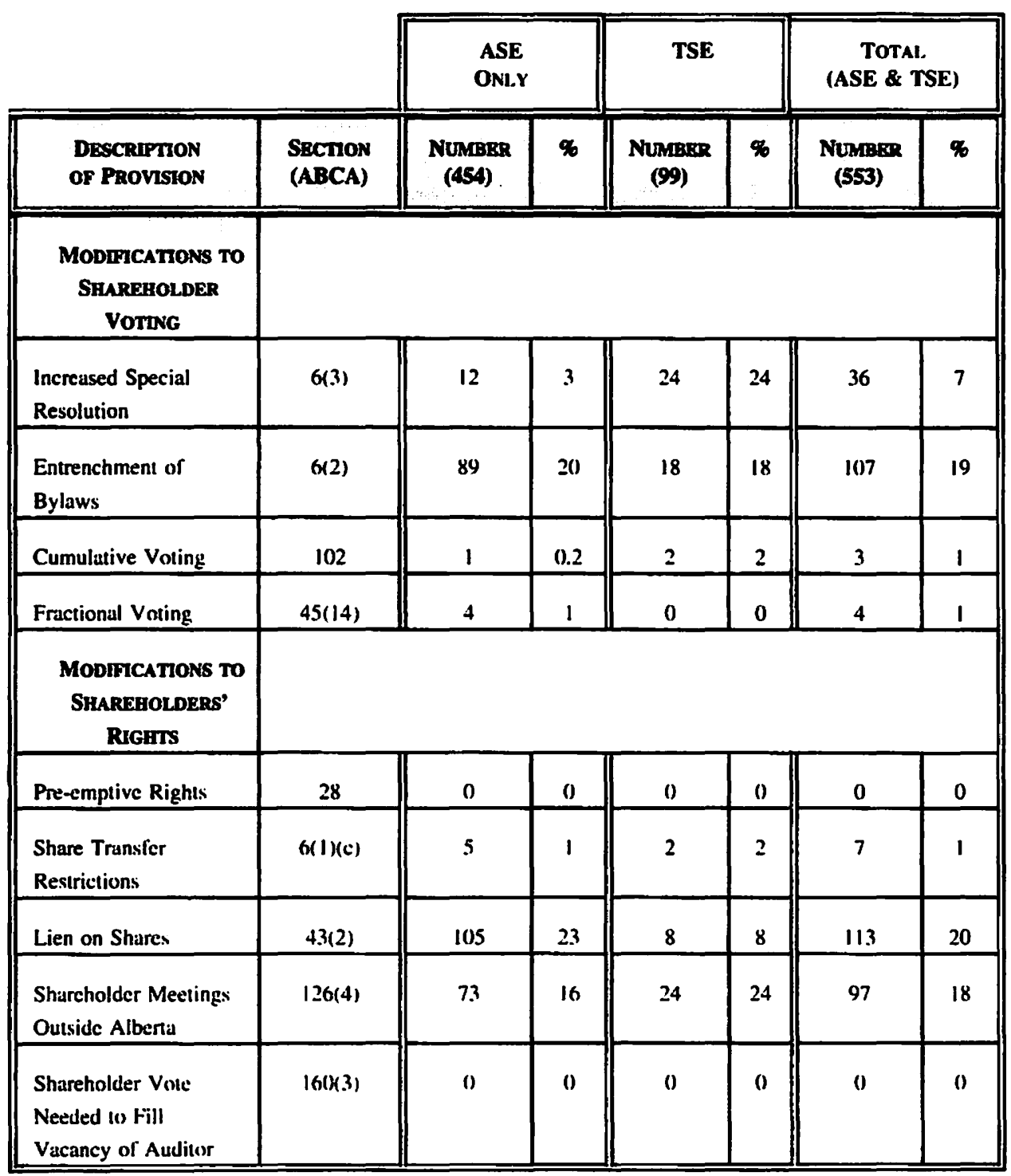


Table B

Constitutional Modifications

TSE Corporations

\begin{tabular}{|c|c|c|c|c|c|c|c|}
\hline \multirow{2}{*}{$\begin{array}{c}\text { DESCRIPTION OR } \\
\text { PROVISION }\end{array}$} & \multirow[b]{2}{*}{$\begin{array}{l}\text { SECTION } \\
\text { (ABCA) } \\
\end{array}$} & \multicolumn{2}{|c|}{$\begin{array}{l}\text { CONTROL.I.ED } \\
\text { CORPORATION }\end{array}$} & \multicolumn{2}{|c|}{$\begin{array}{l}\text { DOMINANT } \\
\text { SHAREHOLDER } \\
\text { CORPORATION }\end{array}$} & \multicolumn{2}{|c|}{$\begin{array}{l}\text { Widet.y HeLd } \\
\text { CORPORATION }\end{array}$} \\
\hline & & $\begin{array}{c}\text { NUMBER } \\
\text { (28) } \\
\end{array}$ & 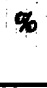 & $\begin{array}{c}\text { Number } \\
\text { (37) }\end{array}$ & $\%$ & $\begin{array}{c}\text { NUMBER } \\
\text { (34) }\end{array}$ & $\%$ \\
\hline \multicolumn{8}{|l|}{$\begin{array}{r}\text { RESTRICTIONS ON } \\
\text { ACTIVITES of } \\
\text { CoRPORATION }\end{array}$} \\
\hline Business Restriction & $6(1)(e)$ & 0 & 0 & 0 & 0 & 2 & 6 \\
\hline $\begin{array}{l}\text { Restriction Against } \\
\text { Self-Purchase of } \\
\text { Shares }\end{array}$ & $\begin{array}{l}32(1), \\
3.3(1)\end{array}$ & 0 & $\mathbf{0}$ & 0 & 0 & 0 & $\mathbf{0}$ \\
\hline \multicolumn{8}{|l|}{$\begin{array}{l}\text { Modifications } \\
\text { RELATING to } \\
\text { Directors } \\
\end{array}$} \\
\hline $\begin{array}{l}\text { Shareholder Vote } \\
\text { Needed to Fill } \\
\text { Vacancy }\end{array}$ & $106(4)$ & 0 & 0 & 0 & 0 & 0 & $\mathbf{0}$ \\
\hline Interim Directors & $101(4)$ & 20 & 71 & 25 & 68 & 20 & 59 \\
\hline $\begin{array}{l}\text { Extended Director } \\
\text { Terms }\end{array}$ & $|(0)|(9)(a)$ & 2 & 7 & 0 & 0 & 1 & 3 \\
\hline $\begin{array}{l}\text { Employee and Creditor } \\
\text { Directors }\end{array}$ & $101(9 k b)$ & 0 & 0 & 0 & 0 & 0 & 0 \\
\hline
\end{tabular}




\begin{tabular}{|c|c|c|c|c|c|c|c|}
\hline \multirow[b]{2}{*}{$\begin{array}{c}\text { DESCRIPTION OF } \\
\text { Provision }\end{array}$} & \multirow[b]{2}{*}{$\begin{array}{l}\text { SECTRON } \\
\text { (ABCA) }\end{array}$} & \multicolumn{2}{|c|}{$\begin{array}{l}\text { CONTROL.I.ED } \\
\text { CORPORATION }\end{array}$} & \multicolumn{2}{|c|}{$\begin{array}{l}\text { DOMINANT } \\
\text { SHAREHOI.DER } \\
\text { CORPORATION }\end{array}$} & \multicolumn{2}{|c|}{$\begin{array}{l}\text { WIDEI.Y HELD } \\
\text { CORPORATION }\end{array}$} \\
\hline & & $\begin{array}{l}\text { NUMBER } \\
\text { (28) }\end{array}$ & $\%$ & $\begin{array}{c}\text { NUMBERR } \\
\text { (37) }\end{array}$ & $\%$ & $\begin{array}{l}\text { NUMBER } \\
\text { (34) }\end{array}$ & $\%$ \\
\hline $\begin{array}{l}\text { Director Share } \\
\text { Qualifications }\end{array}$ & $1100(2)$ & 0 & 0 & 0 & 0 & 0 & 0 \\
\hline $\begin{array}{l}\text { Restriction on } \\
\text { Location of Directors } \\
\text { Meetings }\end{array}$ & $109(1)$ & () & 0 & 0 & 0 & ) & 0 \\
\hline \multicolumn{8}{|l|}{$\begin{array}{l}\text { MODIFICATIONS TO } \\
\text { SHAREHOLDER } \\
\text { VOTWNG }\end{array}$} \\
\hline $\begin{array}{l}\text { Increased Special } \\
\text { Resolution }\end{array}$ & $6(3)$ & 11 & 39 & 6 & 16 & 7 & 21 \\
\hline $\begin{array}{l}\text { Entrenchment of } \\
\text { Bylaws }\end{array}$ & $6(2)$ & 8 & 29 & 7 & 19 & 3 & 9 \\
\hline Cumulative Voling & 102 & 0 & 0 & 1 & 3 & 1 & 3 \\
\hline Fractional Voting & $45(14)$ & $\mathbf{0}$ & 0 & 0 & 0 & o & $\mathbf{0}$ \\
\hline \multicolumn{8}{|l|}{$\begin{array}{c}\text { MODIFICATIONS TO } \\
\text { SHAREHOLDERS' } \\
\text { RIGHTS } \\
\end{array}$} \\
\hline Pre-emptive Rights & 28 & 0 & 0 & () & 0 & 0 & 0 \\
\hline $\begin{array}{l}\text { Share Transfer } \\
\text { Restrictions }\end{array}$ & $6(1)(c)$ & 0 & 0 & 1 & 3 & 1 & 3 \\
\hline Lien on Shares & $43(2)$ & 1 & 4 & 4 & 11 & 3 & 9 \\
\hline $\begin{array}{l}\text { Shareholder Meetings } \\
\text { Outside Albertu }\end{array}$ & $126(4)$ & 7 & 25 & 10 & 27 & 7 & 21 \\
\hline $\begin{array}{l}\text { Shareholder Votc } \\
\text { Needed to Fill } \\
\text { Vacuncy of Auditor }\end{array}$ & $160(3)$ & 0 & 0 & 0 & 0 & 0 & ) \\
\hline
\end{tabular}




\section{ANALYSIS OF RESULTS}

\section{A. RESTRICTIONS ON ACTIVITIES OF CORPORATIONS}

\section{Business Restrictions}

The ABCA brought about a major change in corporate law by the abolition of the ultra vires doctrine. The earlier statute required that the objects of a corporation be set out in its memorandum of association. A transaction that fell outside those powers was not enforceable against the corporation and could not be ratified by the shareholders. ${ }^{37}$ The ABCA eliminates the need to state the objects of a corporation and grants to a corporation the capacity and the rights, powers and privileges of a natural person. ${ }^{34}$

It remains possible to restrict the powers of a corporation under the $\mathrm{ABCA}$. The articles of incorporation may set out "any restriction on the businesses that the corporation may carry on". 35 A corporation may not carry on any business that is restricted by its articles, ${ }^{36}$ and a shareholder, creditor or other complainant may obtain a compliance order directing the corporation to comply with a business restriction. ${ }^{37}$ A contravention of a restriction is also expressly mentioned as a ground for a court ordered dissolution of the corporation. ${ }^{3 \mathrm{H}}$ If the corporation acts in violation of a business restriction, the transaction is not void by reason only that the act is contrary to its articles. ${ }^{39} \mathrm{~A}$ business restriction is only effective against a third party who deals with the corporation if the third party knew or ought to have known of the existence of the business restriction." Registration of the articles of incorporation in the corporate registry is not deemed to constitute knowledge of its contents. ${ }^{41}$ As a consequence, the burden of monitoring a corporation's compliance with a business restriction falls upon the shareholders of the corporation rather than with third parties who deal with it. unless the third party knows of the restriction.

There are two potential groups who may be affected by business restrictions: shareholders and creditors. A business restriction gives shareholders and creditors of the corporation an assurance that the corporation will not engage in a restricted line of business. The shareholders may by special resolution amend the articles to delete or alter the business restriction, ${ }^{+2}$ but this will trigger the appraisal right which permits a dissenting shareholder to exil by requiring the corporation to purchase the shares at fair value. ${ }^{43}$ The creditors of the corporation are less likely to be influenced by the presence

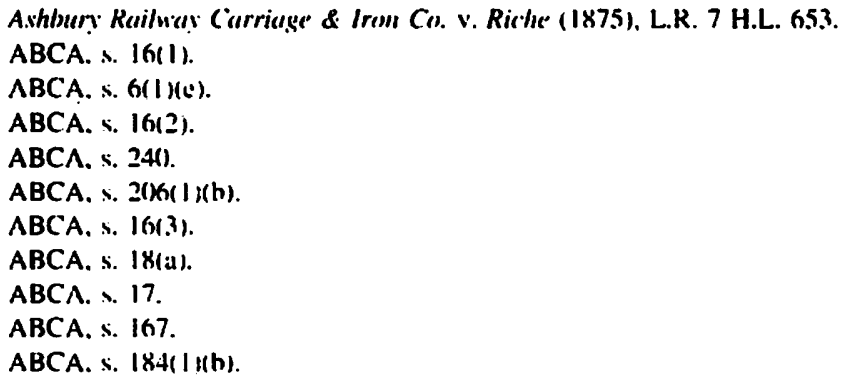


of a business restriction in the articles of incorporation. The creditors have no assurance that the shareholders will not subsequently delete or alter the business and engage in a previously restricted line of business. It is therefore highly unlikely that creditors would rely upon the existence of a business restriction in assessing the riskiness of the debt. A creditor who wishes to restrict the production or investment activities of a corporation will do so by negotiating a covenant in the debt instrument. This device is also more effective since a violation of it will usually be designated as an event of default.

There was a very low incidence of use of business restrictions in the corporations surveyed. Business restrictions were found in the articles of incorporation of only three corporations. In one case, the articles restricted the business of the corporation to a list of broadly described objects which concluded with the power to "engage in any lawful business in which companies incorporated under the laws of the Province of Alberta may engage". This formulation has the effect of completely nullifying the restriction and the result is the same as if no restriction at all had been included in the articles. The provision is similar to an objects clause that was commonly used under the earlier statute, and its inclusion is an example of a failure by the incorporators to fully appreciate the changes brought about by the $A B C A$. In the other two cases, the business of the corporation was restricted to the holding of securities in other corporations.

\section{Purchase of Corporation's Own Shares}

A corporation was prohibited from purchasing its own shares under early corporation law. ${ }^{44}$ The rule against share repurchases by a corporation was originally formulated out of a concern for creditors. Share repurchases were regarded as an unlawful reduction in capital. This idea was directly tied to the conception of limited liability. In place of the liability of its members, creditors of a limited liability corporation were given an assurance that the paid in capital, unless diminished by expenditures made in the ordinary course of business, would be available to satisfy their obligations.

The ABCA rejects an outright prohibition of share repurchases in favour of a two tier solvency test designed primarily for the protection of creditors. ${ }^{45}$ The purchase is prohibited if there are reasonable grounds for believing that the corporation would be unable to pay its liabilities as they become due (the liquidity test). It is also prohibited if the realizable value of the corporation's assets would after the payment be less than the aggregate of its stated liabilities and stated capital of all classes (the assets test). ${ }^{\text {t6 }}$ The assets test is relaxed where the reason for the repurchase is to settle or compromise a debt or claim against the corporation, to eliminate fractional shares, to fulfil an agreement to

4hevor v. Whirworth (1887), 12 A.C. 409.

45 ABCA, s. 32(1) and (2). The Companies Act, R.S.A. 1985, c. C-20, ss. 42.45 contained similar provisions which authorized share purchases if a solvency test was satisfied.

th The stated capital (i.e.. the full amount of consideration received by the corporation for the shares it issues) provides creditors with an additional "cushion". Whereas a conventional fraudulent conveyance test provides creditors with a remedy if liabilities exceed the value of the assets at the date of the transaction, the ABCA prohibits the repurchase if the liabilities and the stated capital exceed the realizablc value of the assets. 
purchase shares from a director, officer or employee, or where the repurchase is required to satisfy a shareholder's dissent and appraisal right where the repurchase is ordered by a court as a shareholder's remedy. ${ }^{47}$ In such cases, it is sufficient if the realizable value of the corporation's assets is not less than its liabilities and the amount required to satisfy the claims of senior equity holders on a liquidation. ${ }^{48}$ These special purposes are given special treatment because they were thought to be "in the interests of the corporation and less likely to be abused than are purchases of the corporation's own shares in general". ${ }^{49}$

On a repurchase, the corporation is required to reduce its stated capital account ${ }^{50}$ and either cancel the shares or restore them to the status of authorized but unissued shares. ${ }^{\text {.1 }}$ A director who consents to a resolution authorizing a repurchase of shares prohibited by the insolvency restriction is liable to restore to the corporation the value of any property distributed. ${ }^{52}$ In addition, a court may order a shareholder to restore to the corporation any money that was paid as a result of a prohibited repurchase if the court is satisfied that it is fair and equitable to do so. ${ }^{53}$

Shareholders are also affected by share repurchases since the shareholders who stay will be treated differently from those who sell. If the repurchase is made at a price greater than fair market value, this will operate to the detriment of the remaining shareholders. The insolvency test will not protect the remaining shareholders from this form of discrimination. These shareholders may seek to invoke a remedy on the grounds that the repurchase is oppressive or unfairly prejudicial to the other shareholders. ${ }^{54}$

The ABCA permits a corporation to adopt a more restrictive rule against share repurchases than the regime set out in the statute by including a restriction in the articles of incorporation..$^{55}$ A corporation is only allowed to opt into a more restrictive regime; it cannot escape the two tier insolvency test by modification of its corporate constitution. A corporation that is subject to a more restrictive share repurchase regime might be more attractive to both creditors and shareholders. Creditors might prefer a blanket prohibition against share repurchases. A flat prohibition is easier for creditors to monitor than an insolvency test which requires an assessment of the realizable value of the corporation's assets. However, a creditor is unlikely to rely upon such an assurance so long as the shareholders may unilaterally alter the corporate constitution ${ }^{\text {s6 }}$ and adopt the more permissive regime set out in the ABCA. Reliance by creditors on such a share repurchase restriction would only be tenable if the corporate law regime did not permit variation of

ABCA. ss. 33(1),(2).

ABCA, s. 33(3).

Alberta Institute of Law Research and Reform. Proposals For a New Alberta Business Corporations Act, Vol. 2 (Edmonton: The Institute, 1980) at 55-56.

ABCA, s. 37(1).

ABCA. s. 37(6).

ABCA, s. 113(1).

ABCA, s. 113(6).

ABCA, s. 234.

ABCA. ss. 32(1), 33(1).

ABCA. s. 167. 
it. Accordingly, one would expect that creditors who wished to restrict potential share repurchases would negotiate a restrictive covenant in the debt instrument.

A prohibition against share repurchases might be attractive to non-controlling shareholders of the corporation. A prohibition against share repurchases could operate as a form of bonding mechanism which gives the shareholders an assurance that management will not engage in opportunistic behaviour to their detriment. ${ }^{57}$ Such behaviour may include the use of a share repurchase to buy off a potential acquisitor in a hostile takeover bid, ${ }^{58}$ to use inside information to repurchase shares when they are relatively undervalued ${ }^{5 \prime \prime}$ or to engage in stock manipulation. ${ }^{\text {"11 }}$ A number of commentators have suggested that there is rarely good reason for a public corporation to repurchase its shares. ${ }^{\text {.1 }}$ If this is so. a prohibition against share repurchases could be used as a low cost method (since it is more easily monitored) of limiting the opportunities for managerial misbehaviour.

The survey of corporations indicates that none of the corporations elected to adopt a more restrictive share repurchase regime. The majority of these corporations surveyed are listed only on the Alberta Stock Exchange ( $82 \%$ of the corporations surveyed). It is possible that a permissive share repurchase regime may be more attractive in a less active market such as the ASE, since it will provide greater liquidity for major shareholders. However, none of the 99 corporations listed on the more active Toronto Stock Exchange adopted a more restrictive share purchase regime.

\section{B. MODIFICATIONS RELATING TO DIRECTORS}

\section{Interim Directors and Filling Vacancies}

The ABCA provides that the articles of incorporation must set out the number of directors or the minimum and maximum number of directors of a corporation. ${ }^{62}$ These directors will then be elected by the shareholders at the annual general meeting. ${ }^{6.3}$ There are two instances in which the directors are given the power to appoint other directors. A quorum of directors may fill a vacancy among the directors ${ }^{\text {t4 }}$ (this may occur upon the death, resignation, removal or disqualification of a director). If there is not a quorum, then a special meeting of shareholders must be convened. ${ }^{\text {s.5 }}$ This ability to appoint

M.C. Jensen \& W.H. Meckling. "Theory of the Firm: Managerial Behaviour, Agency Costs and Ownership Structure" (1976) 3 J. Fin. Econ. 305.

See R.C. Clark, Corporate Lan' (Boston: Littlc, Brown \& Co., 1986) at 631-33.

M.J. Barclay \& C.W. Smith, "Corporate Payout Policy: Cash Dividends versus Open-Market Repurchases" (1988) 22 J. Fin. Econ. 61 at 65. (Ontario: Canada Law Book, 1977) at 119-21. But see Partlell and Burton, "The Share Repurchase Albatross and Corporation Law Theory" (1988) Aust. Law J. 139. 
directors to fill vacancies can be withdrawn by including in the articles of incorporation a requirement that the vacancy only be filled by a vote of shareholders or other voting constituency. ${ }^{\text {th }}$ In addition, if the articles of incorporation so provide, the directors may between annual general meetings appoint one or more additional directors of the corporation to serve until the next annual general meeting so long as the number of directors so appointed does not exceed $1 / 3$ of the number of directors appointed at the last meeting. ${ }^{67}$ This feature is not found in the other jurisdictions that have adopted the BCA model. ${ }^{68}$ The reason for its inclusion was to permit a corporation to make a seat on its board of directors available to a lender or other participant. ${ }^{\text {(t) }}$

The survey of corporations indicates that no corporation adopted a provision that required that the shareholders or other voting constituency to fill a vacancy, but that 322 corporations (58\% of the corporations surveyed) introduced a provision permitting the directors to appoint interim directors. In every case, the articles adopted a minimum and maximum number of directors rather than a fixed number of directors. This associated feature is necessary because the power to appoint interim directors can only be exercised if there are additional positions available under the articles of incorporation.

The Alberta Institute for Law Research and Reform which proposed enactment of the ABCA recognized that the appointment of interim directors might be considered to be an infringement upon corporate democracy and the right of the shareholders to elect the directors. However, it was of the view that the potential for abuse was limited because the contents of the articles of incorporation were under the control of the shareholders and the directors were subject to a fiduciary obligation to act in the best interests of the corporation. ${ }^{70}$ In light of the widespread use of the provision, this issue should given careful scrutiny.

The question should be analyzed across two dimensions. The first involves agency problems that exist between managers and shareholders. The second involves the potential for opportunistic behaviour directed by a majority shareholder against a minority shareholder. In relation to agency problems between managers and shareholders, one may begin with the observation that the issue is largely irrelevant where a corporation with a control group is involved. The controlling shareholder is well-positioned to exercise tight control over the selection of directors (who in many cases will be drawn from the control group), to monitor their performance and to remove them where necessary. In such cases, the addition of individuals with expert knowledge concerning specific projects may be highly beneficial. In addition, the appointment of directors from non-shareholding constituencies may reduce the problem of information assymetries when dealings with

Ontario has adopted a somewhat similar provision which requires that the authority to designate the number of directors must be conferred by special resolution. See Ontario Business Corporations Act. S.O. 1982, c. 4. ss. $124(2)$ and $125(2)$. 
such constituencies. The issue becomes more critical in the case of widely held corporations.

In widely held corporations the board of directors can be regarded as a form of governance device designed to limit the agency costs which are incurred when managers deviate from the interests of the residual claimants (the shareholders). The role of the board is not to review the day to day decisions of management, but to monitor the performance of the chief executive officer," to ratify and monitor major policy decisions, to set executive compensation levels and to search for replacements for top managers. ${ }^{72}$ A particularly acute agency problem exists when the managers propose some transaction which has an element of self-dealing such as entering into a self-interested contract, embarking upon a management buyout or engaging in defensive manouevers to a hostile take-over bid. The ability of the board to monitor such activities requires that the outside directors be independent of management.

The $A B C A$ requires that at least two of the directors of a distributing corporation be independent of the managers of the corporation or its affiliates, but does not mandate that a majority of the directors be independent. ${ }^{73}$ There is evidence that a majority of directors on Canadian corporations are independent directors. ${ }^{74}$ The presence of a majority of independent directors on a board provides some assurance that self-dealing transactions will be scrutinized. The ability to alter the composition of the board without a shareholder vote may give rise to opportunistic behaviour. The inside directors may attempt to orchestrate a change in the board in order to give themselves the balance of power prior to announcing to the board a proposed project that has a self-dealing element to it.

It is important not to overstate this problem. Although complete data is not available, it would appear that there is a controlling or dominant shareholder in a majority of cases in which the provision was included. Indeed, in one instance in which a large widely held corporation adopted the provision, it restricted the number of additional interim directors that could be appointed to one. It is unlikely that the adoption of such a provision is motivated by a desire to tamper with the composition of the board in order to undercut the influence of the independent directors. There may be many real benefits in the flexibility that it provides which outweigh the possibility that the device may be abused.

There is a second kind of agency problem that is of even greater significance in Canada. In the United States the analysis of agency problems between managers and shareholders is central in the debate over corporate law. The higher concentration of

M.A. Eisenberg. The Siructure of the Corporation (Boston: Little. Brown, 1976) at 169-7).

E.F. Fama \& M.C. Jensen. "Separation of Ownership and Control" (198.3) 26 J. L.. Econ. 301 at 313. 15.

ABCA, s. 97(2).

Conference Board of Canada. Camadian Directorship Practices: A Profile 1984, at 19-21. The survey makes the point that "independent" simply means not officens or employees of the corporation or its affiliates. and that some other form of close relationship may often be present. 
corporate control in Canada ${ }^{75}$ implies that agency problems between managers and shareholders is of less significance. The risk is not that the managers will have an incentive to act in their own interests but that they will align their interest too closely with a controlling shareholder and cause the corporation to engage in conduct that benefits the controlling shareholder at the expense of other shareholders. It is possible that the use of independent directors (i.e., directors who are not associated with the controlling shareholder) may operate as a bonding mechanism that provides some assurance to noncontrolling shareholders that the directors consider their interests before approving fundamental changes which may confer unequal benefits among the shareholders. The inclusion of an interim director provision in this context gives rise to a similar potential for mid-stream changes to the composition of the board which undermine its independence.

\section{Extended Director Terms}

Shareholders usually elect directors for a term expiring not later than the close of the next annual meeting of shareholders. ${ }^{76}$ If a term of office is not expressly stated, then the director ceases to hold office at the close of the next annual meeting following his or her election. ${ }^{77}$ An annual meeting must be called not later than 15 months after the holding of the last annual meeting. ${ }^{78}$ The articles of incorporation may alter this default rule by providing for the election of directors for terms not later than the close of the third annual meeting following the election. ${ }^{79}$

Extended director's terms can be used to establish a staggered board of directors in which one third of the board come up for election at each annual meeting of shareholders. A staggered board of directors may be set up to retain continuity. Staggered boards have been adopted by corporations in the United States as a shark repellant (i.e., a device to inhibit unfriendly takeover bids). ${ }^{\mathrm{kI}}$ "This tactic will not succeed under the Canadian business corporation statutes because the shareholders are given the right to remove directors at any time without having to establish that the removal was "for cause" as is the case in some American jurisdictions. The threc year term can also be used to eliminate the need for annual elections in corporations in which the board of directors is not regarded as an important governance device. This might occur where the controlling shareholder is active in the management of the corporation and is regarded as one of the corporation's key assets.

The survey of corporations indicates that 61 corporations included a provision in the articles of incorporation which permitted extended terms of office. An analysis of the

Sec R.J. Daniels and J.G. MacIntoxh, "Toward a Distinctive Canadian Corporate Law Regime" (1991) 29 Osgoxde Hall L.J. 863 at 884-891.

ABCA. s. I()1(3).

ABCA. s. $101(6)$.

ABCA. s. 126(1)(a).

ABCA. $\therefore$ (1)I(t).

R.J. Gilson. "The Casc Against Shark Repellent Amendments: Structural Limitations on the Enabling Cuncept" (1982) 34 Staniord L. Rev. 77.5 at 781-2. But as to the limited efficacy of such provisions, sec 792-6. 
contents of these provisions revealed that in only two cases did the articles expressly establish a staggered board of directors. In the other cases the articles merely provided that the directors could be elected for terms expiring not later than the close of the third annual meeting after their election. Although the failure to specify a staggered board in the articles does not preclude the corporation from setting up a staggered board, the profile of thesc corporations strongly suggest otherwise. The corporations were primarily junior resource corporations or junior capital pools which traded solely on the Alberta Stock Exchange and which had relatively small boards (an average board size of 4.5 directors). By comparison, the two corporations which expressly adopted provision for a staggered boards were larger in size, traded on the TSE. and had an actual board size of 7 and 8 directors. All 61 of the corporations which adopted extended director's terms also adopted an interim director provision.

\section{Employee and Creditor Directors}

The ABCA contains a provision not contained in other Canadian business corporation statutes. Although the directors are normally elected by the shareholders entitled to vote. the articles of incorporation may provide for the election or appointment of directors by creditors or employees of the corporation or by a class or classes of those employees." The statutory duty of a director to act honestly and in good faith with a view to the best interests of the corporation ${ }^{\text {"2 }}$ is modified slightly in the case of a special constituency director. Such a director in considering whether a particular transaction or course of action is in the best interests of the corporation may give special but not exclusive attention to the interests of the special constituency. ${ }^{{ }^{3}{ }^{3}} \mathrm{~A}$ director who represents a special constituency may only be removed by those persons having the power to elect or appoint that director. ${ }^{\mathrm{k}}$

The survey of corporations indicates that none of the corporations have elected to set up special constituency directors. This is not particularly surprising. Although participation by creditors and employees on the board of directors may be desirable in certain cases. ${ }^{\mathrm{ks}}$ the special constituency mechanism may be cumbersome because it requires that the corporate constitution identify the members of the special constituency and specify some further mechanism through which they appoint or elect the directors. Furthermore, the shareholders will always possess the ultimate power to remove the special constituency directors by amending the corporate constitution by special resolution so as to remove the special constituency director provision. ${ }^{\mathrm{K}}{ }^{\mathrm{G}}$ If the presence of special constituency directors is thought desirable. they may be voted in by the shareholders in the normal manner or

ABCA. s. $\mid(1) !(9)(b)$.

ABCA. s. $117(1)(a)$.

ABCA. s. $1(7,4)$.

ABCA. s. $1(1+4(4)$.

Sec O. Williamson. "Corporate Governance" (1984) 93 Yale L.J. I 197 at 1207-1209 (participation of employees on the bourd may he a means of importing credible information to employees) and $1211-1212$ (creditor presence on the board may be warranted when the corporation is in financial adversity).

It is possible that such a move could be regarded as oppressive and found a remedy under section 234 of the ABCA. 
appointed as interim directors by the board in cases where the articles of incorporation contain an interim director provision. The disadvantage of this approach is that the director would not by statute be entitled to give special consideration to the interests of the special constituency. This may not be of great significance because there is Canadian authority for the proposition that the directors may give some consideration to interests other than those of the shareholders. ${ }^{87}$

\section{Director Share Qualifications}

Many of the early Canadian corporations statutes required that a director hold shares in the corporation. The purpose of such a provision was to give the director "a personal interest in the affairs of the company, and to induce him to attend to them in a way very different to what he would do if he had no interest in them at all". ${ }^{88}$ In other jurisdictions this requirement applied only if the articles of association set out a share qualification. ${ }^{\mathrm{KM}}$ The ABCA adopted this latter approach and provides that unless the articles provide otherwise, a director of a corporation is not required to hold shares in the corporation. ${ }^{40}$

The survey of corporations indicates that none of the corporations have included a director share qualification. This is consistent with the changing role of the director. It is recognized that the board of directors of public corporations no longer are involved in the day to day operations of the corporation. The current trend has been towards structuring executive compensation schemes in such a manner as to align the interest of the managers with those of the shareholders." In addition, a simple share qualification is too crude a device. The Dickerson Report made the point that unless the share qualification is substantial, it is meaningless. ${ }^{y 2}$

\section{Location of Directors' Meeting}

The ABCA provides that unless the articles provide otherwise, the directors may meet at any place and on any notice the by-laws require. ${ }^{43}$ The survey of corporations shows that none of the corporations specified the location of directors' meetings. It is possible that this provision was designed primarily for closely held corporations, since the choice of locations might be used as a form of squeeze-out technique designed to exclude one of the participants from the decision-making of the corporation.

Teck Corp. v. Millar (1972), 33 D.L.R. (3d) 288 (B.C.S.C.) (directors may consider the interests of employees and the community). 


\section{MODIFICATIONS TO SHAREHOLDER VOTING}

\section{Increased Special Resolution}

The ABCA requires that certain kinds of structural changes to the corporation be approved by a special resolution of the shareholders. These changes include amendments to the articles of incorporation (known as fundamental changes), ${ }^{94}$ continuance of the corporation in another jurisdiction, ${ }^{95}$ dissolution or voluntary liquidation, ${ }^{, 6}$ reduction of its stated capital, ${ }^{77}$ amalgamations, ${ }^{48}$ and sale or lease of substantially all the assets of the corporation." In some cases the change will also trigger the appraisal right of dissenting shareholders. ${ }^{1(1)}$ A special resolution is defined as a resolution passed by a majority of not less than $2 / 3$ of the votes cast by the shareholders who voted in respect of that resolution."' The ABCA provides that the articles may require a greater number of votes of directors or shareholders to effect any action. ${ }^{102}$ There is one exception to this rule: the articles may not require more than a vote of a simple majority of shareholders to remove a director. ${ }^{103}$

The survey indicaled that 36 corporations provided for an increased voting majority. In all but two cases the corporation was in existence prior to the coming into force of the $A B C A$. These corporations were either continued under the ABCA (i.e., incorporated under the earlier corporations statute and later brought into the $A B C A$ ) or were subsequent amalgamations of corporations that had been continued under the ABCA. In virtually all of the cases, the articles specified $75 \%$ as the threshold needed to pass amendments to the articles. This increased supermajority provision was included only in respect of the preferred shares (and not in relation to the common shares).

The earlier Companies Act of Alberta defined a special resolution as a majority of not less than $75 \%$ of the shareholders who vote. ${ }^{104}$ The retention of the $75 \%$ voting requirement in relation to the preferred shares is likely explained by the special continuance rules of the ABCA, which have no counterpart in other Canadian business corporation statutes. The $A B C A$ required unanimous consent to anything that would amount to a change to the corporation's memorandum of association or articles of association. ${ }^{105}$ The memorandum of association would typically specify a $75 \%$ voting requirement in the case of the amendments to the rights of preferred shares, but would be silent in relation to the common shares. As a result, unanimous consent of the preferred

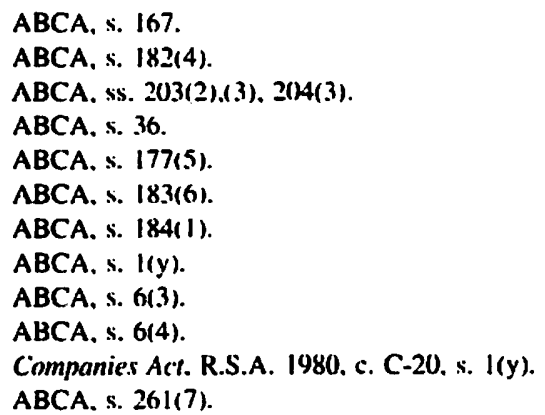


shareholders was required in order to effect a continuance unless the $75 \%$ rule was perpetuated in the articles of incorporation. The results therefore indicate a near universal preference for the lower $2 / 3$ rule of the $A B C A$, since the $75 \%$ rule was retained only where a failure to do so threatened to prevent continuance. The greater incidence of use of such a provision by corporations listed on the TSE as compared with corporations listed only on the ASE simply reflects the fact that the firms listed on the TSE are relatively more established and there is a greater likelihood that they would have issued preferred shares prior to continuance.

In the United States, supermajority charter amendments have been used as shark repellents designed to frustrate the use of two tier takeover bids. A two tier takeover bid involves a bid for less than $100 \%$ of the shares and the shareholders anticipate that the remaining shareholders will be squeezed out on less advantageous terms. A supermajority charter amendment is used to raise the number of votes needed to approve the second tier merger and is usually accompanied by "lock-up" charter amendments which prevents the supermajority provision from being deleted unless the same supermajority is obtained. ${ }^{106}$

The survcy of corporations indicated that there was not a single instance in which the supermajority provisions of the ABCA were used to create a shark repellant provision. There are several contributing reason for this difference. The corporations law of most states require only a majority vote for fundamental changes. The $2 / 3$ special resolution requirement for fundamental changes under the ABCA therefore adopts higher voting threhold as a mandatory rule (although it would be possible to raise the supermajority even higher by utilizing a supermajority provision). In addition the greater concentration of corporate control in Canada means that there are far fewer widely held corporations which are potential targets of a hostile takeover bid. Finally, the use of two tier transactions has reccived a chilly reception in Canada with the result that there is less need to take action to discourage such bids. ${ }^{117}$

\section{Entrenched By-laws}

The ABCA provides that the articles may set out any provision permitted by the Act or by law to be set out in the bylaws of the corporation. ${ }^{108}$ Ordinarily, an amendment to the bylaws must be confirmed by the shareholders by ordinary resolution at the next meeting of shareholders. ${ }^{16 y}$ The effect of including in the articles a provision that would ordinarily be contained in the bylaws is that it will require a special resolution rather than an ordinary resolution to amend or repeal it.

Gilson, supra note 80 at 790 .

Alexunder v. Westeel-Roscos l.dd. (1978), 93 D.1.R. (3d) II6 (Ont. H.C.); O.S.C. Policy 9.1.

ABCA. s. 6(2).

ABCA. s. 98(2). The directors are given the powcr to make, amend or repeal any bylaws but this will only be effective until the meeting of shareholders at which time the shareholders will confirm, amend or reject it. This power may be taken away from the directors if the articles or bylaws so provide. 
The survey of corporations revealed that 107 corporations included in the articles provisions that would ordinarily be found in the bylaws. In every case the articles were modified by the inclusion of two provisions. The first was an authorization to the directors to borrow money, issue debt obligations, give guarantees and create security.interests in the property of the corporation. The second was a provision granting to the directors the power to delegate the director's obligation to manage the corporation to a director, a committee of directors or an officer. The curious thing about this form of modification is that it is not strictly necessary. The ABCA gives the directors these powers without requiring that such a provision be included in the bylaws, ${ }^{110}$ but provides that the articles or bylaws may provide otherwise. Accordingly, there is no need to restate this power in the articles, except that it will prevent an amendment of it by anything other than a special resolution of the shareholders.

The frequent use of this provision may be intended to make it easier for major lenders and financiers to verify that the corporate director or officer has the actual authority to enter into the transaction. Under the ABCA a lender is permitted to rely upon the apparent authority of the director or officer to bind the corporation."' Nevertheless, in major transactions the third party may prefer an assurance that the person has actual authority in order to minimize the possibility of litigation. This can be provided by a review of the articles of incorporation entrenching the borrowing power together with a resolution of directors authorizing the transaction.

\section{Cumulative Voting}

Under the normal shareholder voting system, control of a majority of the shares of the corporation will permit that shareholder to elect the entire board of directors. The ABCA permits the use of a cumulative voting regime if the articles provide for it. ${ }^{12}$ Under a cumulative voting system, each shareholder is given votes equivalent to the number of shares he or she holds multiplied by the number of directors to be elected. The shareholder may then distribute these votes among the candidates. This will often result in candidates of minority shareholders being elected. The articles must specify a fixed number of directors rather than a minimum and maximum number. Other provisions of the ABCA prevent a cumulative voting system from being defeated by an amendment to the articles reducing the number of directors or by a special meeting of shareholders called to remove a director from office. ${ }^{113}$ A cumulative voting system may be eliminated by special resolution. ${ }^{1 / 4}$

The advantages of cumulative voting is that it can give a minority shareholder a presence on the board and may cause other directors to weigh their decisions more carefully because of the presence of an independent self-interested director on the board

III) ABCA, s. 98.1.
III
II2
ABCA. s. 18.
ABCA. s. 102.
I1s
ABCA. s. 104.


who will be alert for signs of self-dealing. ${ }^{115}$ The argument against cumulative voting is that "it encourages the election of directors representing particular interest groups who, by virtue of their partisan role, encourage disharmony in the management of the affairs of the company"."16 The Dickerson Report took the view that the use of cumulative voting may be "more appropriate to small closely held corporations where shareholder control is considered important than to large publicly-held corporations where stability and harmony is considered the dominant interest. ${ }^{117}$ A further argument against cumulative voting is that its use gives disproportionate weight to minority shares thereby creating an agency cost by impeding changes in control. ${ }^{118}$

The survey of corporations indicates that three corporations adopted a cumulative voting system. The number of directors specified by the articles for these three corporations were 5, 11 and 12 directors. In none of these cases did the articles provide for interim directors or extended director terms. This is sensible since these features would tend to frustrate the use of a cumulative voting system.

\section{Fractional Voting}

The ABCA provides that a holder of a fractional share issued by a corporation is not entitled to exercise voting rights or to receive a dividend in respect of the fractional share unless the fractional share results from a consolidation of shares or the articles of the corporation provides otherwise. ${ }^{119}$ Fractional shares may result from a consolidation of shares (or reverse stock split) such as when 100 shares are consolidated into a single share. Fractional shares may also arise out of dividend reinvestment plans in which the corporation issues shares instead of cash to shareholders. The survey of corporations indicate that four corporations included a provision in their articles of incorporation which provided that fractional shares had the right to vote (but were silent as to their right to dividends).

\section{MODIFICATIONS TO SHAREHOLDERS' RIGHTS}

\section{Pre-emptive Rights}

The ABCA provides that the articles may set up a system of pre-emptive rights under which a new issue of shares must first be offered to the shareholders holding shares of that class who may acquire them in proportion to their holdings of the shares. ${ }^{120}$ Notwithstanding the inclusion of pre-emptive rights in the articles, pre-emptive rights are not available to shareholders where the issue is for a non-money consideration, such as

\footnotetext{
11 Clark, supra note 58 at 363.

116 Ontario. Legislative Assembly. Select Committee on Company Law. Interim Report of the Select Committee on Company Law by A.F. Lawrence (Toronto: Queen's Printer, 1967), at para. 8.2.5.

117 Supra note 92 at para. 206.

I1s Easterbrook and Fischel, supra note 9 at 409.

i4 ABCA. s. 45(14).

in ABCA, s. 28.
} 
a share dividend or pursuant to the exercise of conversion privileges or other such rights. ${ }^{121}$

The use of pre-emptive rights is a response to the potential financial dilution and voting control dilution which may occur when an existing shareholder does not participate in new issuance of shares. ${ }^{122}$ Pre-emptive rights were regarded as a proprietary right which attached to the shares in the United States, but this was cut back by the introduction of state legislation which permitted the exclusion of the rule in the corporate charter. ${ }^{123}$ The English and Canadian approach did not recognize pre-emptive rights as a proprietary right in the absence of an express provision creating such a right. Instead, the shareholder was granted relief where the directors were found to be acting in breach of their fiduciary obligations in approving the new issue. ${ }^{24}$ This approach has been retained by the ABCA.

The survey of corporations indicates that none of the corporations include pre-emptive rights in their articles. Indeed, in $\mathbf{5 9}$ cases the articles expressly excluded pre-emptive rights in setting out the rights of the preferred shares (but not in relation to the common shares). This exclusion is not strictly necessary since pre-emptive rights are not conferred unless the articles so provide. The complete absence of pre-emptive rights provisions is not at all surprising since the use of pre-emptive rights by public corporations will greatly increase the costs of obtaining new capital. ${ }^{125}$

\section{Share Transfer Restrictions and Constrained Shares}

The ABCA provides that a distributing corporation shall not restrict the transfer of its shares. ${ }^{126}$ An exception is made in the case of constrained shares. A distributing corporation may amend its articles in accordance with the regulations to constrain the issue or transfer of its shares to persons who are not resident Canadians or to enable the corporation to qualify under any law of Canada referred to in the regulations to obtain licences to carry on business, become a publisher of a Canadian newspaper or periodical or to acquire shares of a financial intermediary. ${ }^{127}$ Regulations defining the parameters of the constrained share system have never been promulgated in Alberta with the result that the constrained share option is not available.

Notwithstanding that share transfer restrictions on distributing corporations are not permitted in Alberta, seven corporations purported to limit the transferability of their shares. Three of these corporations required approval of the board of directors, one provided restrictions in order to protect its status as a Canadian corporation for income

ABCA. s. 28(2).

R.J. Hay, "The Shareholder's Pre-emptive Right: Prevention of Director Abusc in New Share Issuance" (1984) 9 C.B.L.J. 2 al pp. 3.7.

See F.H. Buckley and M.Q. Connelly. Comonrutions: Principles and Policies, 2nd ed., IToronto: Emond Montgomery. 1988) at 212-218.

Sec. c.g., Spomer v. Spomer Oils. Ldd. |19.36| 2 D.L.R. 634 (Alta. S.C.. App. Div.).

The problems associaled with pre-emptive rights and widely held corporations are described in Hay. supra note 122 at 27-8.

ABCA. s. 45(9).

ABCA. s. $168(2)$. 
tax purposes, one restricted transfers that might in the opinion of the directors adversely affect the status of the corporation, one restricted transfers until a specified date, and one provided that the shares were constrained such that not more than $20 \%$ of the shares could be owned by non-resident Canadians. The first three appear to be share transfer restrictions which were originally contained in the articles of a non-distributing corporation but which through inadvertence were not removed when the corporation became a distributing corporation. The others appear to have resulted from a misapprehension concerning the operation of the constrained share provisions.

\section{Lien on Shares}

The ABCA provides that the articles may provide that the corporation has a lien on a share for a debt of that shareholder to the corporation. ${ }^{12 k}$ The lien is ineffective against a transferee who has no actual knowledge of the lien unless reference to it is noted conspicuously on the security certificate. ${ }^{129}$ The earlier Alberta Companies Act was structured so that a share lien provision was included in the corporate constitution unless it was excluded. ${ }^{130}$ The ABCA alters this by requiring this feature to be expressly included in the articles. The survey of corporations indicates that 113 corporations have adopted a share lien provision.

\section{Shareholder Meetings Outside Alberta}

The ABCA provides that meetings of shareholders shall be held at any place within Alberta, but permits meetings to be held outside Alberta at one or more specified places if so provided in the articles. ${ }^{131}$ The survey indicates that the articles of incorporation of 97 corporations made provision for shareholder meetings outside of Alberta.

\section{Vacant Auditor}

The ABCA provides that an auditor is to be appointed by the shareholders of a corporation. ${ }^{132}$ An auditor ceases to hold office when he or she dies or resigns or is removed by resolution of the shareholders. ${ }^{133}$ The directors are empowered to fill the vacancy unless the articles require the office of auditor to be filled only by vote of the shareholders. ${ }^{1.4}$ The survey of corporations indicates that none of the corporations have articles which require a shareholder vote to fill a vacancy.

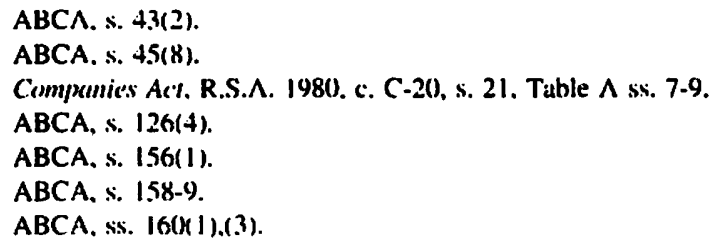




\section{CONCLUSION}

Incorporators of publicly traded Alberta corporations have a limited set of opportunities to contract around the rules of corporate governance by modifying the articles of incorporation. This study finds that most of these opportunities are never utilized. Only six classes of modifications were found to be used to any significant extent. The total incidence of use among all corporations in the survey was as follows:

$\begin{array}{ll}\text { Interim directors } & (58 \%) \\ \text { Lien on shares } & (20 \%) \\ \text { Entrenchment of bylaws } & (19 \%) \\ \text { Shareholder meetings outside Alberta } & (18 \%) \\ \text { Extended director terms } & (11 \%) \\ \text { Increased special resolution } & (7 \%)\end{array}$

Modifications that increase special resolution thresholds can be of great importance. The study finds that the special resolution threshold was increased only when its inclusion was necessary to achieve continuance under the ABCA. A provision normally contained in the bylaws can be entrenched by setting it out in the articles. A special resolution (2/3 majority) is thereafter needed to alter the rule. The study reveals that the provision is used solely to entrench the power of directors to borrow or delegate authority, provisions that shareholders of publicly traded corporations would be unlikely to vary.

Many of the default rules permit the use of modifications that restrict the powers of directors ${ }^{135}$ or that give minority shareholders or other constituencies a voice. ${ }^{1.36}$ These types of provisions are virtually never included in corporate constitutions. Of the six modifications that are frequently adopted, four are used to expand the power of directors. ${ }^{137}$

This includes business restrictions, share purchase restrictions, restrictions on location of meetings of directors, pre-emptive rights, and shareholder voting to till vacancies for directors and auditors. Increased special resolution requirements should also be included because these make it more difficult for directors in effect fundamental changes. This includes cumulative voting schemes and special constituency directors.

i37 The following powers are obtained by directors: (1) the power to appoint interim directors: (2) the power to hold shareholder meetings outside Alberta; (3) the power to create extended terms for directors: (4) the power to borrow unless deprived of this power by special resolution. 